\title{
French nuclear research goes back to basics
}

Paris. For the second time in less than a decade, France's Atomic Energy Commission (CEA) is changing direction. The move has been prompted by the need to justify its huge cost to the taxpayer - FFr6.54 billion (US\$1 billion) annually for civil research alone - at a time when the expansion of nuclear power has virtually come to a halt in the country.

In the mid-1980s, as the research needs of the nuclear industry were beginning to diminish, the CEA sought to redefine its role by expanding its involvement in the industrial applications of its technology. Now it is retreating from direct participation in the development of new technologies, and focusing once again on long-term research underpinning areas such as nuclear technology, reprocessing and safety.

The shift will ease pressure on CEA's finances; research is cheaper than development. Furthermore, many argue that, because CEA is a public body, it should leave industrial ventures and short-term research to commercial companies.

CEA has already started to move in this direction. For example, it has transferred the manufacture of mixed uranium/plutonium (MOX) fuel to COGEMA, France's statebacked nuclear fuel company. Yannick d'Escatha, deputy chairman of the commission, says it will now increase its efforts to find companies to take over its work on other mature technologies, such as the production of integrated circuits, the disman- tling of nuclear plants and industrial robotics.

In future, says d'Escatha, CEA will invest less of its own money in development projects, and instead encourage others to turn its research into new products. One consequence, says d'Escatha, is that CEA will have to involve companies in its research programmes at a much earlier stage than at present.

Another result of this change in direction is that CEA Industrie, the CEA's powerful industrial holding company, is likely to slim down into little more than a technology-transfer company. Last month, for example, it announced that it is giving up its majority shareholding in several high-technology companies; it also plans to reduce its

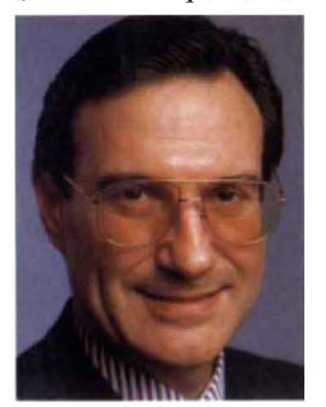
d'Escatha: looking outside the CEA. stakes in other large companies, such as the nuclear engineering company Framatome, when these are privatized.

The 1994 budget for CEA shows the beginning of the shift back to medium- and long-term fundamental research. The budget for research on the separation and incineration of actinides and long-lived fission products is increased 20 per cent, to FFr257 million; that of the use of fast breeder reac-

\section{Immigration law 'a barrier to collaboration'}

Paris. The French government has been accused of dragging its feet on a promise to exempt foreign scientists from clauses in a new immigration law that would prevent them from being joined by their families for two years after their arrival in France.

The promise was made last summer by Charles Pasqua, the Minister of the Interior, after persuading two members of parliament to withdraw amendments that exempted invited researchers from the requirement being imposed on workers from outside the European Union and from the complex administrative procedures now required for visits of even a few days.

But seven months later, Pasqua's promised 'circulaire', which would adjust the way the law is enforced, remains bogged down between the several ministries involved.

Meanwhile, claims Edouard Brezin, the president of the Centre National de la Recherche Scientifique (CNRS), civil servants are "brutally enforcing" the law, and refusing to grant residence to families of visiting researchers. "It's absurd", says Brezin, who has championed the scientists' cause. "How can we invite researchers, and then tell them they can't bring their families?"

Brezin has arranged with the Ministry of the Interior for the entry for several families. But he remains concerned about cases he is unaware of, as well as the impact of the law on potential visitors. "It will destroy our exchanges," he says.

Brezin says he is convinced that Pasqua supports the case for exempting scientists. But he complains that the government has kept him in the dark about the progress of the circular, and expresses concern about apparent resistance in some ministries.

Francois Fillon, the minister for higher education and research, has not been prominent in defending the scientists' cause. Although he officially expressed concern in a letter to Pasqua last June, his ministry was not represented at a meeting in July attended by Brezin and representatives from both the ministries of health and foreign affairs to discuss the circular.

A spokesman for the Ministry of the Interior says that the circular is "blocked" in another ministry. But he refused to comment either on what the circular says, or when it is likely to come into effect. D. B. tors as plutonium furnaces goes up 12 per cent to FFr217 million; and studies on storage of waste will be boosted by 31 per cent, to FFr134 million.

There will also be increased funding for research on the next generation of pressurized water reactors (PWRs, up 27 per cent to FFr172 million), and on the use of mixed oxide fuels (up 18 per cent to FFr115 million). The largest items in the research budget remain dismantling (FFr566 million), PWR safety (FFr509 million) and laser enrichment of uranium (FFr447 million).

In addition, the government has stated that CEA should support long-term research in non-nuclear areas of "scientific, economic or strategic importance" and of an international standard. This will allow the CEA to answer the long-standing criticism that proliferation of its research portfolio - for example, it now has research groups in climatology, particle physics, protein engineering, electronics and radiobiology has taken place in an unplanned way.

Fields now earmarked for increased support, with the backing of both industry and government, include microelectronics and nanotechnology (up 3.6 per cent to FFr375 million), photonics (up 4.5 per cent to FFr 157 million) and radiometry (up 10 per cent to FFr61 million).

One problem facing CEA is adapting its workforce, which has many engineers, to the switch to research. In some fields, CEA has been retiring engineers early and recruiting scientists in their place. But it is being hampered by the overall staff cuts needed to pay for increases in research programmes; staff numbers have fallen from 23,000 to 18,000 over the past five years.

CEA is also having to find the money for a ten-year plan to boost its investment in big equipment. Responding to previous budget cuts, the commission had reduced such spending from around FFr3.2 billion in 1987 to less than FFr1.5 billion in 1992 to maintain spending in other areas. It will now increase by 18 per cent this year.

The overall research budget is growing again after repeated cuts over the past decade. Moreover, the demise of the European Fast Reactor programme is expected to save the CEA about FFr200 million. The commission also intends to close the SATURN accelerator at Saclay near Paris.

Some observers claim that the reforms do not go far enough, suggesting, for example, that the commission should spend more on exploring new ideas for reprocessing. One senior official even argues that CEA should act as the international spokesperson for the French public on nuclear issues, and therefore needs to become completely independent of the nuclear industry. But that is likely to be too radical a step - even for France.

Declan Butler 